\title{
AUSTRALIA AND CHINA- SHARED OBJECTIVES IN APEC AND THE INTERNATIONAL ECONOMIC SYSTEM
}

\author{
ANDREW ELEK
}

The ability of APEC governments to handle short-term financial or macroeconomic crises depends, to a large extent, on awareness of the shared interest in limiting needless underemployment of people and productive capacity. The limited success in terms of responding to the problems which became evident in mid-1997 should not be seen as a failure of APEC leaders in Vancouver, but an indication that more needs to be done to nurture a sense of community in the Asia Pacific. This is not surprising in a remarkably diverse region, whose diversity has been substantially increased by the decision to include Russia in the APEC process.

To strengthen a sense of community, APEC's agenda will need to extend beyond the recent emphasis on liberalising trade and investment. Reducing impediments to international economic transactions remains important. All Asia Pacific economies will benefit considerably from progress towards the 2010/ 2020 Bogor commitments. But the reforms needed will impose short-term costs of adjustment. The cohesion of APEC will depend on exploiting many other opportunities for mutually beneficial cooperation. Economic cooperation to maximise the sustainable growth potential of Asia Pacific economies needs to extend to a broad-based process of development cooperation, not based on one-way transfers of funds, but on a collaborative approach to dealing with the region's problems. The 1996 'Manila Declaration' of APEC ministers set out a framework of principles and priorities for doing so, but much more needs to be done to intensify development cooperation in the region.

As China continues to upgrade its technology and increase the productivity of its human and other resources, it has the widely acknowledged potential to be by far the world's biggest economy. Achieving this will lead to a considerably greater interdependence with other economies. That, in turn, requires much 
greater confidence by China about its access to international markets for inputs as well as outputs, combined with confidence about China's external economic policies by the rest of the world. China has the biggest stake in global free and open trade and investment in the twenty first century, which will be achieved only if APEC provides credible and cohesive leadership in international institutions. Both these considerations point to the need to end the delay in including China in the WTO.

Asia Pacific economies cannot expect to realise their potential for development in isolation from the rest of the world. That is why APEC has consistently sought to promote global, not just regional, objectives by pursuing open regionalism. Up to now, open regionalism has been used to distinguish between MFN or preferential liberalisation of border barriers to trade. As APEC governments develop concrete proposals to facilitate trade and investment-for example by harmonising product standards and administrative procedures - the concept of open regionalism will need to be spelt out in more detail.

As APEC gathers momentum, participants will become increasingly aware of the need to ensure that cooperative arrangements among some participants are indeed capable of subsequent region-wide application. They will also need to ensure that new arrangements do not create new sources of discrimination, thereby fragmenting, rather than integrating regional markets. This is likely to lead to the adoption of principles for cooperative arrangements involving APEC economies which generalise the fundamental General Agreement on Tariffs and Trade (GATT)/WTO principles of transparency, non-discrimination and national treatment, and their application to new issues in international economic cooperation.

Such clarification of the concept and principles of open regionalism is also needed for forging closer economic links between APEC and non-APEC economies. In the medium-term, such links can be expected to emerge from the new Asia Europe Meeting (ASEM) process. In the short-term, APEC economies need to think about ways which will allow Russia to maintain and strengthen its economic ties to Europe in ways which preserve the integrity and cohesion of APEC.

\section{ECONOMICAND TECHNICAL COOPERATION}

The need to respond to short-term economic problems confirms that the scope of economic cooperation in the Asia Pacific can go well beyond its current focus on reducing border barriers to trade and investment. The cohesion of APEC will come under strain as the 2010/2020 deadlines for free and open trade and investment loom closer and APEC governments start to think about exposing their more sensitive sectors to international competition. While the greatest share of the benefits of liberalising highly protected sectors would go to the economies 
which undertake the reforms, this is not the popular perception. It could become difficult to maintain the effectiveness and cohesion of APEC unless the scope of cooperation extends to other matters where the mutual benefits of collective action are more evident.

There are many such opportunities. There is growing awareness that border barriers to trade and investment are not the only important factors which increase the costs and risks of international commerce. Inadequacies of infrastructurefor example, transport and communications facilities - and very different approaches to the regulation of commercial activity are also important issues. The crisis has demonstrated that excessive volatility of exchange rates can be a destabilising influence which weakens the scope for trade and investment among the region's economies.

All of these issues can be addressed, to a significant extent, by a collaborative approach. To be consistent with APEC's fundamental principles of mutual respect and mutual benefit, such cooperation needs to be distinguished clearly from traditional 'foreign aid', which is characterised by one-way flows of money in return for political alliances, preferential access for trade, or enforced changes to economic policies. A new model of development cooperation, suited to the new realities of the region has to rely on a more sound foundation of mutual respect and the mutual beneficial pooling of available information, experience, expertise and technology. As Morrison (1997) has noted

APEC member economies should view development cooperation broadly as a process by
which they work together to develop the entire region in mutually agreed-upon ways, and
not as a process for resources transfers. In this sense, all members are developing economies,
cooperating to achieve common goals such as establishing efficient regional transportation
networks, creating world-class telecommunications links, developing the human resources
needed for economic growth and protecting the Asia Pacific environment.

Since APEC leaders endorsed the objective of intensifying development cooperation in the region in Bogor, there has been extensive discussion of developing a model of economic and development cooperation designed so that all Asia Pacific economies can contribute to, as well as share in, the benefits of collaborative activities. It has been recognised that economic and technical cooperation is not only essential to support progress towards free and open trade and investment, but is an important ingredient in creating a sense of regional community of interests.

The 'Manila Declaration on an Asia Pacific Economic Cooperation Framework for Strengthening Economic Cooperation and Development' sets out a conceptual framework for a new Asia Pacific model of development cooperation, consistent with the fundamental principles of the APEC process of voluntary cooperation. The guiding principles of that declaration indicate that economic and technical 
cooperation among APEC governments will be conducted on the basis of mutual respect, including respect for diversity, autonomy, mutual benefit, genuine partnership and consensus-building. Consistently with the voluntary nature of APEC, as well as to move away from the 'donor-recipient' style of cooperation, activities are expected to involve the pooling of resources such as information, experience, expertise and technology, rather than one-way transfers of funds. All APEC economies are expected to make voluntary contributions, commensurate with their capabilities, and the benefits of cooperation are expected to be shared broadly. Cooperative activities are to promote a working partnership with the private sector and the community in general, to ensure that cooperation is consistent with market principles and the efficient allocation of resources.

According to the Manila Declaration, the six priorities of economic and technical cooperation activities are to

- develop human capital

- develop stable, safe and efficient capital markets

- strengthen economic infrastructure

- harness technologies for the future

- safeguard the quality of life through environmentally sound growth

- develop and strengthen the dynamism of small and medium enterprises.

Well over 300 activities have been proposed by APEC committees and working groups, mostly involving the exchange of information and expertise. Some of these are already underway, but the number of potential cooperative arrangements is growing rather more rapidly than the number implemented. It is also proving difficult to set an order of priority among the many ideas that have been put forward. During 1997, it became evident that economic and technical cooperation among APEC economies is lagging somewhat behind the process of trade and investment liberalisation and facilitation.

\section{INTENSIFYING ECONOMIC AND TECHNICAL COOPERATION}

APEC provides new means of interaction among Asia Pacific political leaders and officials which can lead to innovative ideas and opportunities for cooperative activities. However, it does not follow that APEC institutions are the only vehicles, or even appropriate vehicles, for financing or managing all such activities. Nor should the APEC process restrict its role to becoming just one more means of funding or implementing economic and technical cooperation in the region. The broader challenge is to act as a catalyst for new ideas, to help achieve a high degree of coherence among the activities of all those involved in economic and technical cooperation in the Asia Pacific, while avoiding duplication or creating needless new bureaucratic structures. 
Just as the overall APEC process needs to find constructive ways to complement and cooperate with other institutions such as the WTO, joint efforts to promote economic and technical cooperation among Asia Pacific economies need to find sensible and efficient ways of forging constructive partnerships with the many multilateral, regional and national public and private agencies which are already active in those fields (Table 5.1).

To achieve synergy between all these potential sources of support for economic and technical cooperation among Asia Pacific economies, it will be essential to reach consensus about the comparative advantage of each in terms of financing and/or managing the implementation of the following forms of economic and technical cooperation.

- policy development, such as the exchange of information or expertise and the design of potential cooperative activities

- technical cooperation, such as specific programs to upgrade expertise, institutional capacity or technological capability

- infrastructure-building, especially where additional capacity can benefit several Asia Pacific economies

- financial cooperation to overcome short-term macroeconomic problems. ${ }^{1}$

Different combinations of these four types of economic and technical cooperation are needed in each of the six priority areas identified in the Manila Declaration. For example, human resource development relies mainly on policy development and technical cooperation activities such as training, while infrastructure-building requires a mix of finance and the design of appropriate policy framework relying on the exchange of expertise and experience among APEC officials. All four types can make direct or indirect contributions to trade and investment liberalisation and facilitation (TILF) while joint policy development work and people-to-people exchanges through technical cooperation activities are vital ingredients for nurturing a growing sense of community among APEC participants.

Each of these types of cooperative arrangements has vastly different requirements for funding and for ongoing management. Moreover, various agencies have been pursuing all of these four aspects of economic and technical cooperation since well before the establishment of the APEC process. Their involvement will be essential to implement the new opportunities for economic and technical cooperation which are emerging from the APEC process. For example, at a time of tight budget constraints, the business sector has by far the largest pool of financial resources. Its involvement will be indispensable to finance adequate investment in economic infrastructure during the coming decades, while the direct support of APEC governments will be needed to pursue policy development work as well as many technical cooperation activities. 


\section{THE CHALLENGE FORAPEC}

Compared to the business sector, or to Asia Pacific governments, the APEC process has very modest funds at its disposal. These can be used to fund, at most, a small proportion of the many economic and technical cooperation opportunities it has already identified. This reality need not imply a passive role for APEC, but a serious effort to concentrate on its comparative advantage and to complement the work of others. It should be possible to design a strategy, based on the relative strengths of APEC and other potential sources of support, to pool the region's diverse resources and to mobilise new contributions to economic cooperation and development from all of these sources.

APEC leaders and officials have potential comparative advantage in designing options for economic and technical cooperation which can draw on information, experience, expertise and technology from throughout the region and make it available to many Asia Pacific economies.

These ideas and initiatives can act as a catalyst for intensifying economic and technical cooperation, provided APEC can evoke a positive response to such new ideas from the private sector and from Asia Pacific governments. Relatively small amounts of resources, allocated to relevant policy development work and to forming partnerships with others, could set examples of innovative technical cooperation activities and mobilise considerably larger contributions from others to help implement many of the options for cooperation identified by APEC.

The following examples illustrate how such a catalyst/response strategy for promoting economic and technical cooperation among APEC economies could be applied to some specific activities.

Table 5.1 Agencies active in the Asia Pacific economies

\begin{tabular}{|c|c|c|}
\hline \multirow[t]{2}{*}{ Private sector } & business sector & $\begin{array}{l}\text { individual firms or associations of } \\
\text { firms }\end{array}$ \\
\hline & NGOs & $\begin{array}{l}\text { private foundations, research } \\
\text { organisations and non- } \\
\text { governmental development } \\
\text { organisations }\end{array}$ \\
\hline \multirow[t]{2}{*}{ Public sector } & multilateral agencies & $\begin{array}{l}\text { development agencies such as } \\
\text { United Nations agencies, World Bank, } \\
\text { Asian Development Bank and IMF } \\
\text { Asia Pacific governments acting } \\
\text { individually or in groups }\end{array}$ \\
\hline & APEC institutions & $\begin{array}{l}\text { committees or working groups } \\
\text { reporting to political leaders }\end{array}$ \\
\hline
\end{tabular}




\section{HARNESSING TECHNOLOGIES FOR THE FUTURE}

Policy development work by APEC working groups has already identified many options for pooling technological expertise. Such technical cooperation will be essential to implement many of the opportunities for collective action by APEC governments to facilitate trade and investment. This link is recognised in the Vancouver agreements on early voluntary sectoral liberalisation (EVSL). The programs for early reform in sectors such as energy are to be a combination of technical cooperation and facilitation as well as the liberalisation of border barriers to trade or investment.

Another example is the 'Blueprint for APEC Customs Modernisation' which has been endorsed by APEC leaders. It is a comprehensive program to harmonise and simplify customs clearances by 2000 . Introducing the new procedures will need the development, installation and testing of compatible software for the electronic interchange and processing of customs information, backed by ongoing training for those responsible for applying the new, streamlined procedures.

These proposals, as well as many others for facilitating trade and investment often by means of promoting human resource development- have emerged from the new APEC process. But that does not mean that the costs of such technical cooperation and training need to be financed directly from APEC's budget. Existing development agencies of some Asia Pacific governments, or a regional agency like the $\mathrm{ADB}$, might be persuaded to add some of these activities to their priorities. Moreover, since the business sector is aware of the potential benefits of such facilitation, they should be willing to contribute to the cost of the associated need for technical cooperation, possibly through the new 'Partnership for Equitable Growth', described below. In a few cases-for example, region-wide pooling of expertise and training - cooperative arrangements could be pioneered on a small scale using funds from APEC's modest economic and technical cooperation budget. The subsequent continuation and possible expansion of such 'pilot projects' could be financed by a 'consortium' of businesses and existing development agencies.

Table 5.2 illustrates how policy development APEC working groups (marked by C) could catalyse appropriate responses by the private sector or APEC governments (marked by $\mathrm{R}$ ) to finance and manage the consequent need for technical cooperation. The table also indicates how such a catalyst/response sequence could work in the following examples.

\section{STRENGTHENING ECONOMIC INFRASTRUCTURE}

Even if rates of growth were to slow temporarily in East Asia, there remain many commercially viable opportunities for extending or upgrading economic infrastructure in the Asia Pacific. The volume of investment which is expected 
APEC AND LIBERALISATTION OF THE CHINESE ECONOMY

Table 5.2 Catalysing economic and technical cooperation within APEC

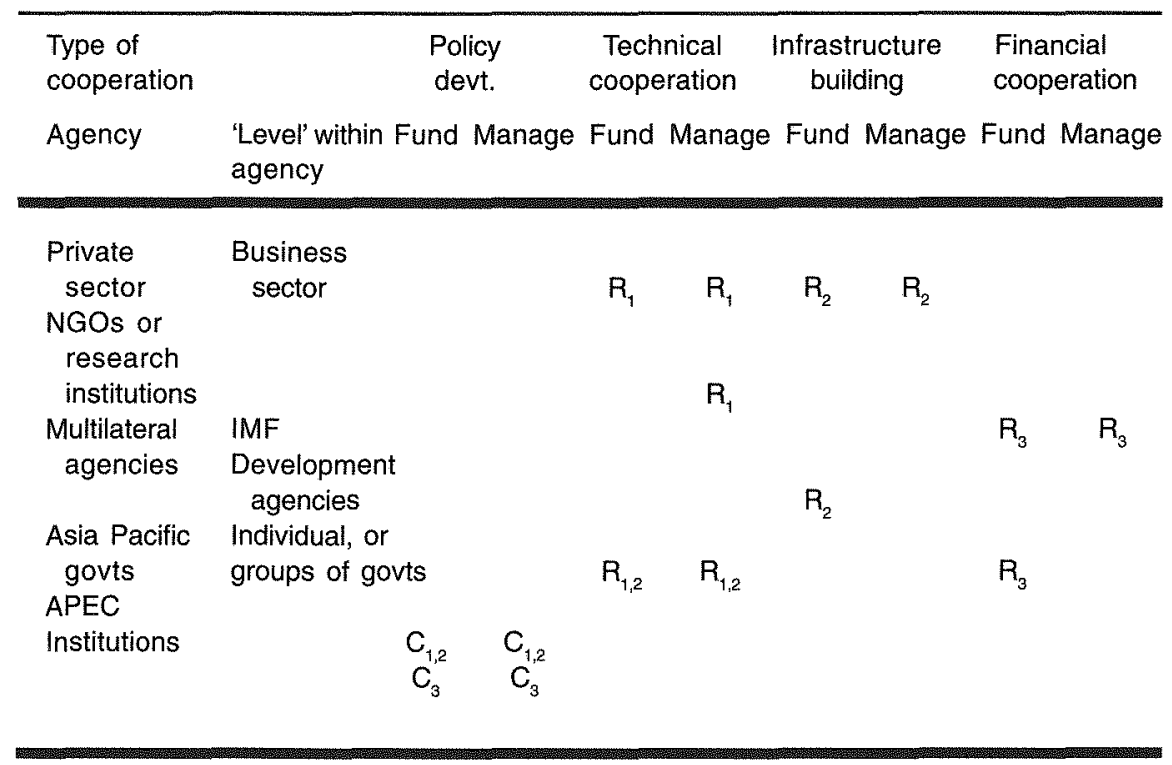

to be needed is well beyond the resources of existing development agencies to provide concessional funding and it is widely accepted that the overwhelming share of investment in such infrastructure-including power generation, transport, telecommunications, airports, harbours, water and sanitation-will have to come from the business sector, either directly or channelled through multilateral or regional development banks such as the ADB. It follows that APEC's economic and technical cooperation is not expected to finance massive public investment in infrastructure, but to improve the efficiency of existing infrastructure and the prospects for private investment in new facilities.

On the demand side, economic forecasting work by APEC committees and working groups can foreshadow the need for timely investments in economic infrastructure. On the supply side, the development and implementation of policy options such as the harmonisation of customs and safety procedures can add significantly to the capacity of existing infrastructure. Policy development work by APEC officials, combined with technical cooperation, can also improve the framework for attracting commercial investment, including by strengthening financial markets or by creating the policy environment needed in cases where several Asia Pacific economies may need to cooperate in order to facilitate investment in infrastructure - for example, in sub-regional power or irrigation schemes. Such strategic inputs and the potential responses in terms of private investment in infrastructure-building are shown by $\mathrm{C}_{2}$ and $\mathrm{R}_{2}$ in Table 5.2. 
STABILISING FINANCIAL MARKETS

By monitoring macroeconomic trends and anticipating potential difficulties, the forecasting work of APEC's Economic Committee and regular communications among APEC ministers can help prepare the ground for rapid responses to potential problems, with some individual APEC governments supplementing the resources which can be made available by the IMF (see $\mathrm{C}_{3}$ and $\mathrm{R}_{3}$ in Table 5.2).

The links which APEC has established among APEC Finance Ministers and their senior officials, and the mutual understanding of the structures and prospects of the region's economies have already proved worthwhile in facilitating a prompt initial response to the short-term macroeconomic and financial sector problems faced by several APEC economies in 1997.

\section{FORGING NEW PARTNERSHIPS}

The prospects for the private sector and existing development agencies taking up and implementing the new ideas for economic and technical cooperation emerging from APEC depend on establishing effective channels of communications and designing effective structures for potential partnerships.

\section{'PARTNERSHIP FOR EQUITABLE GROWTH'}

In its 1997 report to APEC leaders, ABAC confirmed the willingness of the business sector to give direct support to APEC's economic cooperation and development agenda. $\mathrm{ABAC}$ decided to establish a 'Partnership for Equitable Growth' (PEG) to serve as a new framework to encourage business participation in economic and technical cooperation activities, noting that the private sector can add value by undertaking projects in areas where neither the market nor governments currently meet regional needs.

At their 1997 Vancouver meeting, APEC leaders endorsed the PEG concept and also adopted the 'Vancouver Framework for Enhanced Public-Private Partnerships in Infrastructure Development'. Several export credit agencies and export financing institutions have signed a mutual cooperation protocol to enhance the attractiveness of infrastructure investment by the private sector. Objectives to be promoted by encouraging private-public partnerships in infrastructurebuilding include

- creating an Asia Pacific information society

- creating an integrated Asia Pacific transport system

- increased energy infrastructure

- infrastructure for sustainable cities

- infrastructure for rural diversification and integration.

During 1998, it should be possible to implement the first phase of some of these programs using the new PEG framework for forging a new form of 
partnership with the private sector for development cooperation in the Asia Pacific.

\section{PARTNERSHIPS WITH EXISTING DEVELOPMENT COOPERATION AGENCIES}

There are reasonable grounds for confidence that the development agencies of APEC governments, multilateral and regional development banks will respond positively to challenges to finance and/or implement new ideas for economic and technical cooperation proposed by APEC leaders.

APEC governments can exercise considerable influence over the priorities of their own international development agencies. Some existing agencies--such as Australia's AusAID - have already provided funds and made arrangements for the management of some technical cooperation priorities identified by APEC working groups. The Chinese government could, together with others, encourage all existing development agencies to shift their emphasis to supporting projects of region-wide significance emerging from APEC committees and working groups, rather than projects with a narrower, bilateral focus.

Once APEC governments have set some priorities for technical cooperation and infrastructure development, they have considerable potential collective influence over the priorities and activities of multilateral development agencies, particularly the ADB. Such development agencies have the institutional capacity to raise the funds required and to select firms best qualified to construct physical facilities and for the day-to-day management of projects.

In these ways, APEC governments can use the policy development capacity of APEC committees and working groups and a modest budget for innovative technical cooperation activities to mobilise substantial commitments from other sources. Moreover, the private sector and existing development agencies can take on the task of implementation. In some cases, private sector interest can be sharpened by contributions from APEC governments with a particularly strong interest in certain forms of economic and technical cooperation.

\section{GLOBAL FREE AND OPEN TRADE AND INVESTMENT}

Intensifying economic and technical cooperation using the mechanisms described above will help APEC governments to implement proposals for reducing impediments to trade and investment. Nurturing a sense of community through practical and mutually beneficial collective actions will also pave the way for APEC to tackle the liberalisation of 'sensitive' sectors early in the next century, by means of consensus-building rather than confrontation.

China, Australia and other APEC economies also need to develop a strategy for promoting free and open trade and investment globally, rather than just within the Asia Pacific region. An open, non-discriminatory global economy is needed 
to accommodate the expected growth of China's economy and trade. It is not realistic to expect that all of the structural changes necessarily will be restricted to within the Asia Pacific. China has the biggest stake in free and open trade and investment and its continued commitment to 'opening to the outside world' is a vital ingredient in sustaining the progress of all APEC economies towards the agreed 2010/2020 targets.

APEC's track record so far is encouraging. APEC governments have implemented the undertakings for 1997 in the 'Manila Action Plan for APEC'2, while the prospects for sustaining the pace of reform have been improved in several ways. First, by strengthening the Individual Action Plans (IAPs) of APEC economies; second, by the nomination of 15 sectors-ranging from energy and chemicals to food and telecommunications-for early voluntary liberalisation. ${ }^{3}$ Proposals for individual and collective actions in nine of these sectors are expected to be endorsed by Trade Ministers in mid-1998.

The sectors agreed for early liberalisation do not include the most sensitive sectors such as agriculture or clothing. However, it is realistic to apply new approaches to sectors where consensus is expected to be relatively easy to reach. Moreover, early agreements will prevent these from becoming the sensitive sectors of the future. The unilateral decision of APEC governments for completely free trade in information technology products in 1996 was followed swiftly by a corresponding WTO-wide agreement. Once APEC governments begin to implement programs for EVSL, they will be justified in expecting a similar response from the rest of the world, improving the prospects for tackling other difficult areas globally.

As the 2010/2020 deadlines approach and attention turns towards the 'sensitive sectors' of each Asia Pacific economy, all governments will need to make politically difficult decisions, in order to help other APEC participants to make correspondingly difficult decisions. It is quite possible that these decisions, involving different sectors in different economies, will need to be orchestrated by negotiations. But that does not imply that the APEC process should be transformed into a negotiating forum. The WTO has been specifically designed for conducting such negotiations and has the advantage that all significant economies take part.

It is very difficult to imagine either East Asia or the United States dismantling all of the protection of their agriculture sectors unless the European Union (EU) is prepared to act similarly. Such globally concerted decision-making could be achieved through WTO negotiations, while APEC economies continue their voluntary cooperation on many other less contentious matters.

Engaging the attention of the rest of the world and providing collective leadership in the WTO, as well as in other multilateral organisations like the IMF, will require APEC governments to act cohesively to promote their interests. 
That in turn requires determined attempts to avoid inevitable friction over international trade or investment from leading to unilateral threats of retaliation. It also requires that all APEC economies become members of the WTO.

The post-Uruguay Round dispute settlement procedures are working well and there has been less inclination to try to settle issues by unilateral threats rather than by reference to the WTO. However, the WTO dispute settlement mechanism is not available to China (or to Taiwan and Russia). China's entry to the WTO has been blocked up to now, primarily by the United States, preventing prospects for a real sense of community within the Asia Pacific and APEC governments exercising their full potential for positive collective influence in international forums. ${ }^{4}$ Europe is also a problem.

Australia can help to resolve the issue of China's inclusion in the WTO by making an unequivocal statement that, in its view, China's commitment to 'opening to the outside world' and its record of extensive reforms in that direction over the past two decades justify its immediate full membership of the WTO, with an unconditional right to most-favoured nation (MFN) treatment by all other members. There is room for improvement in China's trade policies, but these can be addressed through subsequent negotiations or, in some cases, by referring issues to the WTO's dispute settlement procedures. The time has come for Australia to address China's inclusion in the WTO in a strategic way, rather than looking for tactical negotiating opportunities, while hiding behind the United States on this matter.

\section{THE FUTURE OF OPEN REGIONAIISM}

The concept of open regionalism has been critically important to APEC since its inception in 1989, reflecting the deep concern of East Asian economies in sustaining and strengthening an open global trading system. There are three main reasons why the Asia Pacific region has adopted a non-discriminatory approach to regional economic cooperation (Garnaut 1996; Drysdale et al. 1997).

First, it is impractical to consider regional trade liberalisation by means of a conventional discriminatory free trade area of the kind sanctioned by the GATT/ WTO. The substantial elimination of trade barriers through the negotiation of a free trade area is simply not attainable within the Asia Pacific region, especially following the inclusion of Russia in APEC. Any attempt to negotiate such an arrangement would be highly divisive and delay the process of liberalisation it was supposed to promote (Elek 1995). It would corrode the objective of community-building and lead to the exclusion of major players inside the region who are not yet members of the WTO (such as China, Russia and Vietnam) as well as APEC's neighbours and trading partners. Hence APEC has opted for an alternative, new approach: setting targets for trade and investment liberalisation, rather than negotiating 'free and open trade and investment in the region'. 
Second, the trading interests of East Asian and the Pacific economies extend beyond APEC, including to Europe. A conventional free trade area strategy towards trade liberalisation would deter internationally-oriented reform in the region's developing economies and introduce tensions into relations with major partners outside the region. As already noted, emerging giant economies like China (hopefully followed by Indonesia and Russia) can only be accommodated in a global economic system.

Third, trade discrimination involves the unnecessary costs of trade diversion, complicated in the Asia Pacific region by the likelihood of high associated political costs both within and outside the region (Garnaut and Drysdale 1994: Chapter 5).

APEC's agenda has evolved around giving progressively more precise expression and effect to the idea of open regionalism and this process must continue. The GATT/WTO principles of transparency, non-discrimination and national treatment apply strictly only to trade in goods, which dominated international commerce when the GATT was set up in the 1940s. These fundamental principles have yet to be extended systematically to cover other international economic transactions, such as trade in services, and international investment.

Similarly, up to now, the concept of open regionalism has been used to distinguish the reduction of border barriers to trade in a non-discriminatory-or MFN-basis from preferential trading arrangements. As APEC economies enter into new cooperative arrangements to facilitate trade and investment, they need to define how open regionalism can be applied effectively beyond trade in goods; to new areas for cooperation where there are few significant multilateral disciplines against discrimination.

The very different economic structures of the 21 participants of APEC, combined with diverse cultures, political systems and decision-making procedures, can make it difficult to prioritise and act on shared economic interests; one or more APEC participants may resist, or wish to delay, any specific proposal for practical cooperation. It makes sense to expect groups of APEC participants to implement cooperative arrangements to facilitate trade and investment at different speeds. The 'Osaka Action Agenda' contains an explicit provision for some Asia Pacific economies to set examples of cooperative arrangements which can be applied region-wide once their benefits become clear.

Such flexibility can promote the early initiation of cooperative activities to facilitate trade and investment and to exchange expertise and technology. However, such flexibility also carries some risks. Thoughtful management will be needed to ensure that 'variable geometry' does not create needless confusion or divisions by neglecting the interests of other economies. It is possible - and indeed imperative - to find ways to ensure that cooperative arrangements involving some APEC economies take careful account of the interests of others and 
promote the smooth evolution of region-wide arrangements. In other words, APEC governments will need to design and adopt guidelines which encourage the design of 'open clubs'.

\section{DESIGNING 'OPEN CLUBS'}

The main characteristics of 'open clubs' are that they

- do not seek to disadvantage outsiders

- have transparent 'rules', including transparent criteria for admitting new members

- actively promote wider membership.

Few clubs meet all of these conditions, but such criteria can distinguish those clubs which are genuinely seeking to meet high standards of 'openness'. Correspondingly, it is possible to set guidelines or criteria for cooperative arrangements which are designed to reduce impediments to trade or investment consistently with the concept of open regionalism.

Cooperative arrangements to facilitate economic transactions among groups of economies are typically implemented by adopting certain norms for policies which influence such transactions. For example, the 'policy norms' to implement the 1996 decision by Australia, Korea and the Philippines to introduce a streamlined system for business travel, provided for agreed and transparent procedures for the issue of visas and electronic processing of travellers with such visas, making it feasible for others to join once the procedures had been found to be helpful. By the end of 1997, several other Asia Pacific governments volunteered to join the scheme.

Many other options are available for some Asia Pacific economies to set examples for others. An arrangement for the mutual recognition of disclosure requirements and auditing standards for firms would need the economies involved to adopt some agreed norms, or minimum standards, of accounting. If these norms are clearly documented and others are encouraged to adopt them then such mutual recognition arrangements would also be open clubs.

Cooperative arrangements can be described as open clubs if the policy norms of the arrangement are transparent, do not contain provisions which discriminate against products or producers from other economies, and all economies which adopt the relevant policy norms have the right to accede to the arrangement. It is not easy to meet all of these criteria.

It is technically possible to reduce border barriers to trade in ways which do not discriminate against products from any source; this is usually described as liberalisation on a MFN basis. For trade in goods, Article 1 of GATT/WTO requires MFN treatment-at least of products from WTO members-except in some special circumstances, for example in the context of preferential trading arrangements which comply with Article XXIV. 
Beyond trade in goods, there are fewer restrictions on discrimination. It is also more difficult to design cooperative arrangements which do not discriminate in some ways against other economies, either by design or by default. For example, free and open trade in services and free and open investment require national treatment of producers as well as of products.

Arrangements to facilitate international economic transactions will tend to divert economic activities even in the absence of any explicit provisions which discriminate against products or producers from other economies. Such arrangements typically involve agreements by a group of governments to adopt a certain set of more convergent, or more compatible, policies. Since these arrangements are designed to reduce the costs or risks of economic transactions among one group of economies, they will create an added incentive for transactions within the group compared to transactions with others.

In some cases, the resulting diversion of trade and investment may be unintended and insignificant. In other cases, diversion may be exacerbated and entrenched by explicit discrimination against products or producers from other economies. Those outside such cooperative arrangements can often reduce any disadvantage to them by voluntarily adopting the relevant policy norms. However, to avoid any diversion they usually need to be admitted to the arrangement.

There are several issues which need to be considered and resolved in designing cooperative arrangements involving APEC economies (Appendix 1). It is not always easy to reduce impediments to international economic transactions without detriment to other economies. It is not surprising that, in practice, markets are fragmented in various ways, not only by explicitly preferential trading arrangements, but also by many other cooperative arrangements among groups of economies. Therefore, if APEC participants want to ensure that cooperative arrangements pioneered by some APEC economies set positive examples and take account of the interests of others, they will need to devise and adopt principles to help ensure that arrangements for practical cooperation take full account of the interests of others and encourage them to join such arrangements.

In designing such guidelines, it is important to follow the basic principle of evolutionary cooperation, acknowledging that complete transparency and nondiscrimination are ideals which can only be approached, rather than fully achieved. However, it is possible to agree on ways to ensure that all new arrangements do indeed contribute to an international trading system which is less fragmented and less discriminatory than it is now, and that becomes progressively closer to these ideals.

For example, in relation to trade in goods and services, the WTO has adopted the combination of 'standstill' and 'roll-back' to promote a gradual trend towards non-discriminatory free trade. The liberalisation of border barriers to trade, by individual governments or groups of governments, is expected to reduce some 
barriers without raising existing ones or creating new obstacles. Such a strategy can be generalised to promote cooperative arrangements to reduce impediments to all international economic transactions.

APEC's already agreed-upon principles of 'standstill' and the commitment to endeavour to apply the principle of non-discrimination can be given effect by guidelines which stipulate that new cooperative arrangements involving APEC economies should not lead to new discrimination. It will also be necessary to generalise the concept of national treatment to deal with the issues involved in reducing impediments to trade in services as well as to international factor movements. Accordingly, new arrangements should not contain any provisions which create additional or new forms of discrimination among products or producers, either on the basis of the location of various stages of production or the 'nationality' of producers.

To be effective, the principles for cooperative arrangements involving APEC economies will need to contain provisions for review of both proposed and existing arrangements. First, prior notice can enhance the prospects of more economies joining these new arrangements at the outset. Second, as illustrated by the examples in Appendix 1. It is not easy to ensure that cooperative arrangements among some economies are genuinely open clubs. While they may be designed in good faith to meet APEC's agreed guiding principles for trade and investment liberalisation and facilitation, their implementation could cause unexpected problems for other economies. Therefore, those involved in these arrangements should be willing - once again in good faith - to respond to constructive suggestions from other economies on how to improve the consistency of these cooperative arrangements with agreed guiding principles.

\section{GENERAL PRINCIPLES OF OPEN REGIONALISM}

Based on these considerations, the principles proposed below build on those of the 'Osaka Action Agenda', generalising the concept of open regionalism as well as the fundamental principles of transparency, non-discrimination and national treatment which lie at the heart of the GATT/WTO system.

APEC economies that are ready to initiate and implement cooperative arrangements to reduce impediments to economic transactions or to promote economic and technical cooperation are encouraged to do so, while taking account of the interests of other economies as follows.

\section{TRANSPARENCY}

(i) The policies adopted to implement these arrangements should be documented explicitly (typically expressed in legislation or regulations of those economies) and be freely available and accessible, through convenient channels of communication. 
(ii) APEC economies should provide reasonable prior notice of the nature and objectives of proposed cooperative arrangements as well as the policies by which these are to be implemented.

\section{NON-DISCRIMINATION}

The arrangements should not contain any provisions which result in new or additional discrimination, either against products on the basis of the location of production, or among producers on the basis of their place of registration or ownership.

\section{ACCESSION}

(i) Any economy whose government accepts the responsibilities as well as the benefits of following policies compatible with any existing or proposed cooperative arrangements among some APEC economies should be able to, and encouraged to, become parties to these arrangements.

(ii) Existing parties to these cooperative arrangements should be willing to share the information, experience, expertise and technology needed to enable others to adopt the relevant policies.

\section{REVIEW}

APEC economies should endeavour to respond positively to constructive suggestions from other economies for improving theconsistency of existing or proposed cooperative arrangements with APEC's agreed guiding principles for liberalising and facilitating trade and investment.

As APEC gathers momentum, participants will become increasingly aware of the need to ensure that cooperative arrangements among some of them are indeed capable of subsequent region-wide application, as well as the need to avoid the proliferation of arrangements which fragment, rather than integrate, regional markets. This is likely to lead to the adoption of principles along these lines to promote the design of cooperative arrangements which are 'open clubs', consistent with these criteria.

Such principles or guidelines are likely to prove very useful in adapting cooperative arrangements which have been implemented in other regions in order to make them consistent with the Asia Pacific model of open regionalism. Most of the options for facilitating or liberalising trade and investment under consideration in the Asia Pacific have already been implemented in other processes of regional economic cooperation. It would be unwise and inefficient for APEC economies to ignore this experience. On the other hand, such arrangements have not always been designed to be 'open clubs'. Most existing cooperative arrangements among groups of economies contain provisions which discriminate explicitly among products and/or producers, thereby creating new market 
distortions. Moreover, few existing arrangements have well-defined means of accession which can overcome short-term vested interests against wider participation and will need to be modified to fit APEC's style of cooperation.

Once adopted, such principles can also serve as a framework for the design of cooperative arrangements involving both APEC and non-APEC economies. For example, the recently initiated ASEM process is likely to lead to some practical cooperative arrangements to lower the costs and risks of trade and investment between European and East Asian economies. If such arrangements were consistent with the proposed principles, they would be quite consistent with the interests of other APEC participants who are not part of the ASEM process.

The inclusion of Russia in APEC adds to the need for such principles. Russia's economic links with Europe and with other former members of the Soviet Union are considerably stronger than with other APEC economies. This balance will change, but Russia will certainly wish to be free to strengthen economic links with trading partners outside, as well as within APEC. If Russia can be encouraged to abide by the principles proposed for new arrangements involving APEC economies, then such links can contribute to APEC's ultimate objective of reducing impediments to global, rather than just regional, trade and investment.

\section{CONCLUSION}

The East Asian financial crisis has been a test of the cohesion of APEC and demonstrates the need for APEC to broaden its horizon beyond trade and investment. China and Australia can work together to help resolve crises of confidence in parts of the region. Australia can also play a more helpful role in ending the delay in China's inclusion in the WTO.

China and Australia can help to intensify development cooperation in the region, building on the conceptual framework of the Manila Declaration. There are many opportunities for forging new partnerships with existing development cooperation agencies, as well as with the private sector, to implement some regional economic and technical cooperation activities identified by APEC working groups. Training programs which share the experience and expertise needed to facilitate early voluntary sectoral liberalisation could be a good starting point.

In addition to ensuring that the commitment to early liberalisation of some sectors proceeds on schedule, the time has come to think ahead and develop a strategy for global action to deal with those 'sensitive sectors' which are less likely to be opened up through unilateral, voluntary decisions by individual governments. APEC's guiding principles will also need to be refined to ensure that cooperative arrangements involving some APEC economies take full account 
of the interests of all other economies. This will be important as sub-groups within APEC start to implement arrangements for economic and technical cooperation or to facilitate aspects of trade and investment among themselves. Such principles are also needed to help ensure that practical arrangements for facilitating trade or investment between some APEC economies and nonparticipants-for example, arrangements emerging from the new ASEM process-remain consistent with the coherence of APEC.

These are complex matters. APEC officials and leaders will take some time to understand and address these issues. Some if not all of them will need further attention in 2001, when China takes up the leadership of APEC. There is an opportunity for Chinese and Australians, with shared interest in the future of APEC and of the international economic system, to work together to propose and promote ways to address emerging issues in Asia Pacific cooperation. 


\section{APPENDIX 1 \\ PROPOSED STRENGTHENED PRINCIPLES FOR APEC}

APEC's flexible approach to cooperation allows Asia Pacific governments to determine the sequence of unilateral liberalisation to dismantle border barriers to trade and investment. It also allows groups of APEC governments to implement cooperative arrangements - either to facilitate trade and investment or to intensify economic and technical cooperation - at different speeds. However, they will need a strategy for managing such 'variable geometry'.

As discussed in this chapter, the remarkable diversity of Asia Pacific economies means that it would be counter-productive to insist that all APEC participants be involved in every specific initiative for cooperation. Accordingly, the 'Osaka Action Agenda' encourages those APEC participants who are ready to implement cooperative arrangements to do so ahead of others. This provision can promote rapid progress as long as the initiatives taken by some are positive examples which are designed to maintain the cohesion of APEC and to provide practical means - as well as incentives - to widen the coverage to include all of the region. At the same time, such a ' 21 - $X$ ' provision carries some risks. As already remarked upon, initiatives by some APEC economies to facilitate trade or investment could sow the seeds of division and confusion if these arrangements neglect, or damage, the interests of others. Instead of promoting further marketdriven integration of Asia Pacific economies, they could lead to an inefficient and needless fragmentation of markets.

Experience to date with regional economic cooperation indicates that most arrangements to reduce impediments to international economic transactions among one group of economies tend to divert economic activity away from the rest of the world. In some cases, such as preferential trading arrangementssometimes called 'free trade areas' - the diversion is intended. In other cases, the diversion may be an unintended by-product of practical steps to reduce the costs or risks of trade or investment among some economies.

The following examples illustrate how the policy norms of various cooperative arrangements can be designed to take account of the interests of others and encourage them to join the arrangements in order to share in the benefits, while avoiding any unintended diversion of economic activity.

\section{TRADE IN GOODS}

APEC governments have agreed to dismantle all barriers to trade in all goods in a WTO-consistent manner by 2010/2020. Each government will set its own schedule for eliminating - unilaterally-its tariffs and any other border barriers to trade in goods by their respective deadlines. 
APEC participants have rejected the option of setting up a formal trading arrangement, so Article 1 of the GATT/WTO will ensure that unilateral liberalisation of border barriers does not discriminate against any member of the WTO. Therefore, as long as all APEC economies join the WTO in the near future, unilateral liberalisation will not lead to any new discrimination.

However, the majority of APEC participants also belong to formal sub-regional preferential trading arrangements, so such unilateral reductions of tariffs and non-tariff barriers to trade in goods will be accompanied by liberalisation within these arrangements. Article XXIV of the GATT/WTO permits liberalisation within these groups to be preferential; that is, to proceed faster than liberalisation with respect to other economies, raising the prospect of some new discrimination by some APEC participants.

Fortunately, most Asia Pacific governments are aware of the advantages of non-discriminatory liberalisation. In practice, liberalisation within sub-regional arrangements is being accompanied by unilateral, non-discriminatory reduction of border barriers to trade. Both Australia and New Zealand have lowered trade barriers against the rest of the world while eliminating barriers to bilateral trade. ${ }^{5}$ In the 1996 Manila Action Plan for APEC, ASEAN governments have confirmed that, as well as liberalising trade within AFTA, they would also continue to lower tariffs unilaterally against all trading partners. Some of them-including Indonesia and the Philippines - have indicated that they will extend the liberalisation committed within AFTA to all members of the WTO.

Members of NAFTA are not expected to extend the liberalisation within that preferential trading arrangement to other economies. In that case, there would be some short-term diversion of economic activity away from other APEC economies. The extent of new trade diversion could increase if, as planned, all North and South American economies form a preferential Free Trade Area of the Americas. However, members of NAFTA are committed to eliminate border barriers to trade and investment in the Asia Pacific by 2010.

For these reasons, the 'WTO-consistency' principle of APEC provides an adequate-and also critical — guideline for limiting discriminatory liberalisation of trade in goods on the way to meeting the agreed 2010/2020 targets.

\section{TRADE IN SERVICFS}

Free and open trade in services requires more than the elimination of border barriers to the delivery of services. It will also be necessary to remove artificial distinctions in the way policies apply among services-for example on the basis of how they are delivered - or to 'domestic' and 'foreign' providers of services, leading towards the national treatment of all firms. 
At present, there are few multilateral restraints to prevent governments from discriminating between 'domestic'and 'foreign' firms, or among 'foreign arms' of different 'nationality'. In practice, most cooperative arrangements to liberalise trade in services extend a greater degree of national treatment only to service providers from the economies involved. Other things being equal, such arrangements will divert activity away from economies which are not parties to these arrangements.

The design of practical guidelines for liberalising trade in services among APEC economies must take into account that it would be unrealistic to expect all arrangements to move from highly fragmented markets to automatic MFN treatment of all service providers. The immediate challenge is to ensure that cooperative arrangements to liberalise trade in services among some APEC economies can serve as a stepping stones'to wider arrangements.

For example, it would be counter-productive to expect to move from a system of bilateral agreements on international aviation - most of which are designed to limit competition - to free and open trade in aviation. In practice, reform is likely to proceed by the liberalisation of existing bilateral arrangements towards 'open skies' agreements and the subsequent linking of such agreements to cover more and more of the region. In other service sectors, the liberalisation of trade in services may advance most rapidly within existing sub-regional arrangements. This will rely on the acceptance of guidelines for cooperative arrangements on services which can ensure that liberalisation among some groups of APEC economies will lead smoothly towards the Bogor vision of free and open trade in services.

In line with APEC's 'standstill' principle, such guidelines should rule out any arrangements that create new sources of discrimination either among services or among service providers on the basis of their 'nationality'. While it might be unrealistic to expect all new cooperative arrangements to lack any preferential features, it will be important to anticipate that preferential arrangements tend to set up vested interests to resist the inclusion of additional economies. This suggests criteria to ensure that cooperative arrangements are transparent and provide for the unconditional accession of any economy whose government adopts the policy norms agreed upon by existing parties.

\section{HARMONISING ADMINISTRATIVE PROCEDURES}

APEC participants are already implementing a proposal for the electronic interchange of customs information and harmonised clearance procedures. This arrangement is likely to be an 'open club'. The arrangement is not designed to favour any particular sector or economy, but to reduce the costs, uncertainties and delays of customs processing. The resulting improvement in the efficiency of infrastructure will be maximised if more economies join the arrangement. 
Accordingly, all APEC economies are expected to take part in the new cooperative arrangement. They also have an incentive to pool the relevant expertise and technology needed to allow all of them to implement the new procedures quickly and smoothly. Moreover, the benefits will be increased if all exporters to, or importers from, APEC economies also adopt the same procedures for customs documentation and clearance, so there are strong incentives for transparency and no incentives for discrimination against non-participants.

This initiative for facilitating trade is just one of the many opportunities for reducing the costs and risks of international economic transactions by promoting more convergent or more compatible procedures for the administration or regulation of commercial activities by groups of governments. There will normally be clear benefits from maximising transparency. The economy-wide benefits of such arrangements to facilitate international economic transactions would be enhanced by widening the group. However, since many of these arrangements are likely to be preferential, they will favour producers within the arrangement relative to outsiders, and there may be sectoral pressures against widening. Therefore it will be helpful to set up guidelines which ensure that new arrangements among groups of APEC economies do not create new sources of discrimination and make clear provisions for accession.

\section{MUTUAT, RECOGNITION OF STANDARDS}

The evolution of the EU has demonstrated how a cooperative arrangement for the mutual recognition of product and process standards is an essential ingredient of any serious effort to create an integrated market. Experience in Europe and elsewhere has also demonstrated the potential for standards to become new means of protection.

By definition, only those economies which adopt and monitor adherence to comparable standards can be party to mutual recognition arrangements. Since the relevant products can be traded more conveniently among the parties to the arrangements, there will be an incentive to divert some economic activities away from other economies.

If the mutually recognised standards are not transparent, then other economies will certainly be disadvantaged. However, if all the relevant standards are transparent, then producers from any economy can choose to conform to them. If the procedures for demonstrating compliance to these standards are also transparent and applied without discrimination, then products from any source could be marketed in all the economies within the mutual recognition arrangement after being tested in any one of them. Producers from outside the arrangement would still be at some disadvantage compared to those within, since they would still need to have their product tested by agencies of one of the parties to the mutual recognition arrangement. However, such residual disadvantage could 
also be eliminated if their governments were able to become full parties to the arrangement.

Accession should be feasible if the arrangement makes it clear that any economy which adopts the policies required to implement the arrangement are automatically entitled to join. To join an arrangement for mutual recognition, prospective parties would not only need to adopt comparable standards, but also demonstrate their willingness and ability to monitor their producers' compliance with such standards (with comparable certainty as in existing parties). That may require the strengthening of some institutions which may depend on the willingness of existing parties to share the necessary information and expertise.

\section{TECHNICAL COOPERATION}

Many of the proposals for facilitating trade and investment will require the training of people from Asia Pacific economies in the techniques and procedures needed to administer new approaches, such as a harmonised system for recording and processing information needed for customs clearance or for monitoring conformance to mutually recognised standards.

It is sensible to set up joint programmes for training. The smooth administration of such schemes relies on adequate mutual trust in the capacity of counterparts in other Asia Pacific economies to manage the jointly agreed procedures. By far the most efficient way is for these people to be trained similarly in an environment where personal mutual respect can be established. It is therefore quite likely that many such regional training facilities will be established. The private sector, through ABAC's proposed 'Partnership for Equitable Growth', has indicated its willingness to help finance such initiatives.

It is not necessary to wait for all APEC participants to show interest in participating in each training program before they can be embarked upon by some. To be consistent with the spirit of open regionalism, the curriculum and materials should be designed to be relevant to all of the region and be freely available for information and for comment. Moreover, all economies should be encouraged to send people to be trained, provided they take on responsibilities reasonably comparable to those who are already doing so-for example, by bearing the same share of the travel and other costs incurred by trainees, together with a contribution to the costs of the programme in line with other economies with similar attributes.

\section{GUIDING PRINCIPLES}

The preceding examples of options to liberalise and facilitate trade and investment and to promote technical cooperation are by no means exhaustive. However, they are sufficient to illustrate that it is not simple to design such cooperative 
arrangements while avoiding any detriment to, or excluding, other economies. Therefore, it is not surprising that, in practice, markets are fragmented in various ways, not only by explicitly preferential trading arrangements, but also by many other cooperative arrangements among groups of economies.

All such arrangements create an incentive for others to join, in order to avoid any trade or investment being diverted from their economies. At the same time, any arrangements which divert economic activity create vested interests against widening by those who benefit from such diversion. That makes it difficult to keep these 'clubs' open, unless clear rules for accession are built in from the outset. Moreover, many cooperative arrangements to facilitate international economic transactions, such as double-tax agreements or arrangements for mutual recognition of product and process standards, are technically complex to administer. Even if their policy norms are transparent, it will be difficult for others to adopt them in order to join such arrangements, unless those already involved are willing to share the relevant expertise and technology.

These considerations suggest that some guidelines are needed if cooperative arrangements among any groups of economies are to be 'open clubs'. In particular, if APEC participants want to ensure that cooperative arrangements pioneered by some APEC economies set positive examples and take account of the interests of others, they will need to devise and adopt principles for practical cooperation which build on those in the 'Osaka Action Agenda'.

The following criteria may be useful to help ensure that all cooperative arrangements involving APEC economies are consistent with the spirit of open regionalism and which, by taking full account of the interests of all APEC participants, can preserve the cohesion of APEC.

Transparency. Perfect transparency may be an ideal, but it is possible to agree on criteria which cooperative arrangements involving APEC economies should meet. For example, guiding principles for transparency could require that the policies and procedures adopted for these arrangements be set out explicitly, typically in their legislation or regulations. These should be freely accessible to all governments and producers who wish to do so. In practice this can be achieved by preparing (where applicable) an authoritative translation into English, which is the working language of APEC. The policy norms of 'open clubs' should be available to all those interested, free of charge, through one of the more recognised channels. In 1998, that would probably be on a World Wide Web site accessible, among many other ways, through the APEC Secretariat's 'home page'.

A second important aspect of transparency is prior notice of new arrangements (or significant amendments to existing arrangements). This can enhance the prospects of more economies joining these new arrangements at the outset. Prior notice can also allow governments of other economies to comment on the 
terms of the proposed arrangements. Such comments could improve the effectiveness of these arrangements and help to make them as consistent as possible with APEC's guiding principles for trade and investment liberalisation and facilitation.

Non-discrimination. For trade in goods and services, the WTO has adopted the combination of 'standstill' and 'roll-back' to promote a gradual trend towards non-discriminatory free trade. The liberalisation of border barriers to trade, by individual governments or groups of governments, is expected to reduce some barriers without raising existing ones or creating new obstacles. Such a strategy can be generalised to promote cooperative arrangements to reduce all impediments to all international economic transactions.

APEC's agreed principles of 'standstill' and the commitment to 'endeavour to apply the principle of non-discrimination' can be given effect by guidelines which stipulate that new cooperative arrangements involving APEC economies should not lead to new discrimination. It will also be necessary to generalise the concept of national treatment to deal with the issues involved in reducing impediments to trade in services as well as to international factor movements. Accordingly, new arrangements should not contain any provisions which create additional or new forms of discrimination among products or producers, either on the basis of the location of various stages of production or the 'nationality' of producers.

Accession. As shown by the preceding examples, cooperative arrangements to facilitate trade or investment will tend to divert economic activities to the economies involved. Moreover, those who benefit from the diversion of trade or investment - intended or unintended - will tend to resist accession by additional economies. Therefore, if cooperative arrangements involving APEC economies are to be genuinely open to accession, their design will need to anticipate and minimise such resistance.

To a large extent, this can be achieved if the arrangements are highly transparent and do not create new discrimination among products or producers. In addition, the arrangements should specify at the outset, that the only condition for accession by additional economies will be their demonstrated ability to follow policies consistent with the arrangements. Many arrangements to facilitate trade or investment are technically complex; they will be 'open clubs' only if existing members are willing to share the requisite information, experience, expertise and technology. The 1996 Ministerial 'Declaration on an Asia Pacific Economic Cooperation Framework for Strengthening Economic Cooperation and Development' commits all APEC participants to such pooling of resources.

Review. As shown by the earlier examples of facilitation, it is not easy to ensure that cooperative arrangements among some economies are genuinely 'open clubs'. 
While they may be designed, in good faith, to meet APEC's agreed guiding principles for trade and investment liberalisation and facilitation, their implementation could cause unexpected problems for other economies. Therefore, those involved in these arrangements should be willing to respond to constructive suggestions from other economies on how to improve the consistency of these cooperative arrangements with agreed guiding principles. Proposed principles. A concise set of principles based on these concepts, building on APEC's current guiding principles as well as the fundamental GATT/WTO principles of transparency, non-discrimination and national treatment have been proposed for consideration within this chapter.

\section{REFERENCES}

Asia Pacific Economic Cooperation (APEC), 1991. 'Seoul APEC Declaration', Ministerial Declaration, Singapore.

_- 1996. 'Manila Declaration on an Asia Pacific Economic Cooperation Framework for Strengthening Economic Cooperation and Development', Ministerial Declaration, Singapore.

— 1995. 'Osaka Action Agenda', endorsed by APEC Ministers, November. Drysdale, P. and Elek, A., 1992. 'China and the international trading system', Pacific Economic Papers, No. 214, Australia-Japan Research Centre, The Australian National University, Canberra.

Drysdale, P., Elek, A. and Soesastro, K., 1997. 'Open regionalism: the nature of Asia Pacific integration, in D. Vines and P. Drysdale (eds), Europe, East Asia and APEC: a shared global agenda, Cambridge University Press, Cambridge.

Elek, K., 1995. 'APEC beyond Bogor: an open economic association in the Asian-Pacific region', Asian-Pacific Economic Literature, 9(1):1-16.

Foundation for Development Cooperation (FDC), 1997. Economic and technical cooperation and the APEC process: issues for consideration, paper prepared for meeting at ISIS Malaysia, Kuala Lumpur.

Garnaut, R., 1996. Open Regionalism and Trade Liberalisation, ISEAS, Singapore.

Garnaut, R. and Drysdale, P. (eds), 1994. Asia Pacific Regionalism: Readings in International Economic Relations, Harper Collins (in association with the Australia-Japan Research Centre), Sydney.

Hai Wen, 1996. China's accession to the WTO and its role in APEC, paper prepared for the Europe, East Asia and APEC Conference, Australia-Japan Research Centre, The Australian National University, Canberra. 
Morrison, C., 1997. Building an Asia-Pacific community: development cooperation within APEC, in A. Elek (ed) The Foundation for Development Cooperation, Brisbane.

Pacific Economic Cooperation Council (PECC) Trade Policy Forum, 1996. Perspectives on the Manila Action Plan for APEC, PECC Secretariat, Singapore.

\section{NOTES}

1 For more detailed descriptions of these four types of economic and technical cooperation, see FDC (1997).

2 Independent studies, including by the Pacific Economic Cooperation Council (PECC) indicate that, if sustained, the pace of liberalisation of border barriers to trade is on track for meeting the 2010/2020 deadlines agreed in Bogor in 1994. (PECC Trade Policy Forum (1996).

3 The 15 sectors identified for early voluntary sectoral liberalisation are

- environment goods and services*

- fish and fish products*

- toys*

- forest products*

- gems and jewellery*

- oilseeds and oilseed products

- chemicals*

- energy sector*

- food sector

- natural and synthetic rubber

- fertilisers

- automotive sector

- medical equipment and instruments*

- civil aircraft

- telecommunications mutual recognition arrangements.*

Detailed proposals for economic and technical cooperation, facilitation and liberalisation are to be prepared by mid-1998 for the nine sectors marked with an asterisk.

4 The urgency of admitting China to the WTO, with unconditional rights for most-favoured-nation treatment, have been set out in many publications, including Drysdale and Elek (1992), Wen Hai (1996) and Elek (1996) and will not be elaborated upon here.

5 Since no APEC participant belongs to any customs union (such as the EU), nothing prevents them from lowering trade barriers to outsiders at any pace they choose. 